\title{
MALAY MANUSCRIPTS AND EARLY PRINTED BOOKS AT THE LIBRARY OF CONGRESS
}

\author{
A. Kohar Rony
}

This article has two purposes.Its primary purpose is to describe the Library of Congress holdings of Malay manuscripts and early printed books in terms of their provenance and contents and to highlight the role played by the nineteenth-century missionary Alfred North in acquiring most of the collection. The second purpose is to begin to suggest the significance of the documents for Malay studies. The Library's holdings of Malay manuscripts, although limited in extent, concern the history and literature of the Malay world in the first half of the nineteenth century. Unlike twentieth-century imprints, which are generally accessible in North America and elsewhere, these early volumes may be the only copies extant.

Before describing the provenance and contents of the collection, it is important to clarify the special way in which the terms "Arabic script" and "Malay" will be used throughout this article. The term "Arabic script" here denotes the Arabic writing system adapted to the Malay phonetical system. In Indonesia, such a writing system is referred to simply as huruf Arab, in Brunei, Malaysia, and Singapore, as huruf jawi. The term "Malay" will be used to refer to the name of the language as opposed to the scripts in which the above texts were written. Indigenous to the island of Sumatra, and in use long before the birth of the modern states of Brunei, Indonesia, Malaysia, and Singapore, the Malay language developed over

I wish to thank Miss Asma Ahmat of the National Library of Malaysia, who did her internship at the Library of Congress in 1989-1990, for sharing with me her knowledge of our Malay collections. While assigned to the Asian Division, she undertook a special project of listing and describing the Malay manuscripts and early printed materials. The data for the description of such materials discussed in this paper is derived from her report of the project, "Report on the Library of Congress Malay Manuscripts and Early Printed Books." I also want to thank Lou Jacob and Warren Tsuneishi, both of the Library of Congress, Annabel Teh Gallop of the British Library, Kent Mulliner of Ohio University, Dorothy Rony, Joseph Saunders, and Philip Lee Thomas for their invaluable criticism and suggestions. 
the centuries from being the mother tongue of coastal Sumatrans to being the lingua franca of trade and the learned language of the entire Malay archipelago. The early Malay manuscripts and early printed books to be discussed in this article are part of the body of literature of the people who used the Malay language. In this sense they are the cultural heritage of the Malays of modern-day Malaysia, but also of those in Brunei, Indonesia, and Singapore.

The Malay manuscipts and early printed books in the Library of Congress were not described until recent times. Although Horace Poleman reported four of the titles in A Census of Indic Manuscripts in the United States and Canada, ${ }^{1}$ nobody seemed to take note of them. Perhaps the title of the census itself was a little misleading, and it may have been assumed that it concerned only Indian manuscripts.

It was not until Professor A. Teeuw came to visit the Library of Congress in 1966 that our Malay manuscripts were first brought to the attention of scholars. I remember how pleasantly surprised he was when I showed him the collection. In the following year, he published a brief article in the Bijdragen tot de taal-, land-, and volkenkunde, reporting the existence of eight of the Library's Malay manuscripts. ${ }^{2}$ Soon thereafter, we began to receive inquiries about them, as well as requests for photocopies. A positive microfilm copy of the eight manuscripts can now be purchased from the Library of Congress Photoduplication Service.

Most of the Library of Congress Malay manuscripts, and a few of the early printed books, bear the so-called "Smithsonian Deposit" stamps, which are to indicate that they were first acquired by the Smithsonian Institution from the Wilkes Exploring Expedition (1838-1842). The expedition was so named because it was commanded by Captain Charles Wilkes, a US Naval Officer who had earlier explored the Antarctic region. Authorized by the Congress of the United States, the Wilkes Expedition included naturalists, botanists, mineralogists, taxidermists, and, most importantly from our profession's point of view, a philologist. I imagine one of the purposes of the mission was to collect and bring back examples of "native" culture, and the philologist was there to help identify and select Malay manuscripts and other publications. When the members of the expedition reached Singapore in February 1842, they were greeted by the US Consul, Joseph Balestier and his wife, Maria Revere Balestier, and also by an American missionary, Alfred North, who was stationed there. It was North who helped the expedition acquire not only the Malay manuscripts and early printed books, but also other manuscripts written in the Bugis script, the script of the Buginese people of South Sulawesi.

As part of an agreement worked out in 1865, the Smithsonian transferred major parts of its collections, including the Malay manuscripts and early printed materials acquired through the Wilkes Expedition, to the Library of Congress. By the close of the year 1866, Librarian of Congress Aisnworth Rand Spofford was happy to announce the transfer of "this large accession ... especially valuable in the range of scientific books, comprising by far

${ }^{1}$ Horace I. Poleman, A Census of Indic Manuscirpts in the United States and Canada (New Haven: American Oriental Society, 1938).

${ }^{2}$ A Teeuw, "Korte Mededelingen: Malay Manuscripts in the Library of Congress," Bijdragen tot de taal-, land-, en volkenkunde 123, 4 (1967): 517-20. 
the largest collection of the journals and transactions of learned societies, foreign and domestic, which exists in America." This came to be called "The Smithsonian Deposit."

At the present time, these manuscripts and the printed books are in the custody of the Southern Asia Section of the Asian Division in the Library of Congress. They are housed in a secured area, although access is available to any legitimate researcher.

\section{III}

The Malay manuscripts consist of fourteen codices and a bound volume containing handwritten correspondence and letters with officials seals to the Chief British Resident in Singapore from heads of state in what are now Brunei, Cambodia, Malaysia, and Indonesia. As I have mentioned earlier, eight of the manuscripts were described briefly by Professor A. Teeuw in 1967. These were Kinta Buhan, Isma Dewa Pakurma Raja, Kitab Khoja Maimun, Hikayat Amir Hamzah, Hikayat Johor, Hikayat Patani, Hikayat Muhammad Hanafiah, and Hikayat Abdullah. Twenty years later, in 1987, Harun Mat Piah described them in greater detail in an article in Sari. ${ }^{3}$

The six additional codices are as follows:

1. Hikayat Panca Tanderan, also known as Galila (or Kalila) dan Damina. Four Indian tales translated by Abdullah bin Abdul Kadir with the help of one Tambi Matubar Fafatar. Malacca [handwritten by Abdullah bin Abdul Kadir] 1835. Folio. 67 p., $29.3 \times 21.7 \mathrm{~cm}$. Laid paper; 12 lines

Written in black ink with rubrication for chapter headings and punctuation words, the handwriting is neat and large. There is vowelization of names and of countries, etc., which are difficult to pronounce. Office.

Binding: softboard, covered with marble paper, bound at the Singapore Free Press

Contents: 1. Galila Damina Sakralaum. -2. Sendi Bikrawam. -3. Arta Nasam. -4. Sambi Tarica Kariwum.

2. Kitab Tib: pengetahuan segala ubat-ubat adanya. Singapore [Handcopied by Abdullah bin Abdul Kadir?] 1837. Quarto. 41 p. 19.7 x 16.5 cm., 13 lines.

Bluish white English laid paper. Watermarks: "Joseph Coles," "1836," and image of Britannia in a crowned circle.

Binding: softbound covered by marble paper, quarter binding.

Discusses medicinal values of honey, ginger, black pepper, etc.; medicines for coughs, constipation, sinus; Malay charms used to cure sickness caused by demons and spirits.

3. [Four Tales] Singapore [handcopied by Muhammad Arif] 1837. Quarto. 154 p. $18 \times 15$ cm., 11 lines.

Bluish white English laid paper. Watermarks: "J. Coles," “1834," 1835," “1835," "1836," and a mark of a lion in a crowned shield.

${ }^{3}$ Harun Mat Piah, "Manuskrip-manuskrip Melayu dalam Koleksi Library of Congress Amerika Syarikat," Sari 5 (1987): 3-15. 
Written in black ink in a firm, neat hand, with certain words rubricated, e.g., punctuation words, names, and Arabic phrases.

Binding: soft cardboard covered by marble paper; quarter binding.

Contents: 1. Hikayat Abu Sahmah. A story about Abu Sahmah, the son of Umar and his sentencing by Umar according to Islamic laws. -2. Hikayat bulan belah dua. - 3. Hikayat Saerah dan Hadhri. - 4. Hikayat Derma Taksiah.

4. Hikayat Syah Mardan. Singapore [Handcopied by Muhammad Arif, a teacher in the Raffles Institution] 1837.

Quarto. 230 p., 19.5 × $14.7 \mathrm{~cm} ; 13$ lines.

Blue English laid paper. Watermarks: "Joseph Coles," "1836," and an image of Britannia in a crowned circle.

5. Hikayat Isma Yatim. Malacca [copied by Ismail, 1837?]

Quarto. 268 p., $22.5 \times 18 \mathrm{~cm}$., 17 lines. Woven paper, yellowish white. 23 gatherings numbered in Arabic in red ink.

Written in black ink in firm, neat handwriting, with rubrication of punctuation words and Arabic phrases.

Binding: bound in softboard covered with marble paper and quarter leather.

6. Kitab Adat segala Raja-raja Melayu dalam segala negeri. Singapore [copied by Abdullah bin Abdul Kadir, 1837]

Quarto. 90 p., 19.5 x 16 cm., 13 lines. Bluish white Egnlish laid paper. Watermarks: "Joseph Coles," "1835," and a mark in the shape of Britannia in a crowned circle.

Written in black ink with rubrication of punctuation words.

Binding: softboard covered with marble paper. Quarter binding.

An earlier copy dated 1819 belonged to Datuk Sulaiman of Kampung Melayu Malaka. Datuk Sulaiman was Abdullah's teacher mentioned in his Hikayat Abdullah. The original work was done in 1779 at the request of the Dutch Governor De Bruin.

The bound volume of correspondence contains early nineteenth-century official correspondence from heads of state in neighboring Southeast Asian countries to William Farquhar, British Resident in Singapore. This is an important source of information about the early period of British domination in Southeast Asia from the point of view of Southeast Asian political leaders. Altogether, the correspondence numbers forty-seven letters consisting of the following:

a. Three letters from Brunei to Colonel William Farquhar, British Resident of Singapore:

(1) From Sultan Muhammad Khan Zul Alam ibn Sultan Omar Ali Saifuddin, dated 5 Rejab 1236 (8 Apr. 1821);

(2) From Sultan Muhammad Khan Zul Alam ibn Sultan Omar Ali Saifuddin, dated 6 Syaaban 1237 (28 Apr. 1822);

(3) From Pangeran Muda Muhammad Alam ibn Sultan Muhammad Khan Zul Alam to Tambi Muhammad ibn Arsyad of Malacca, dated 7 Syaaban 1237 (29 Apr. 1822); 
b. A letter from Tuan Syed Abdul Hamid bearing the title of "Nak Cu Pa of Rapadi?" Kambuja to Colonel William Farquhar, British Resident of Singapore, dated 4 Jamadil Akhir 1235 (18 Feb. 1820);

c. Seven letters from Raja Bendahara of Johor-Pahang to Colonel William Farquhar, British Resident of Singapore:

(1) Undated;

(2) Dated 30 Syaaban 1234 (24 Jun. 1819);

(3) Dated 1 Zulkaedah 1234 (22 Aug. 1819);

(4) Dated 10 Ramadhan 1235 (21 Jun. 1820);

(5) Dated 24 Ramadhan 1236 (25 Jun. 1821);

(6) Dated 10 Zulhijjah 1236 (8 Sept. 1821);

(7) Dated 10 Syaaban 1237 (2 May 1822); pore;

d. A letter from Dato Bendahara of Johore-Pahang to Syed Syarif Umar Jamid of Singa-

e. A letter from Yang Di Pertuan Kelantan and Tengku Syed Abdul Rahman bin alHabib Hussein Aidid to Colonel William Farquhar, British Resident of Singapore, dated 3 Syaaban 1237 (25 Apr. 1822);

f. A letter from Dato Penghulu Naning to Colonel William Farquhar, British Resident of Singapore, undated;

g. Three letters of Pengeran Dipati from Palembang:

(1) addressed to Colonel William Farquhar, British Resident of Malacca, dated 7 Jamadil Akhir 1234 (3. Apr.1819);

(2) addressed to Colonel William Farquhar, dated 7 Jamadil Akhir 1234 (3 Apr. 1819);

(3) addressed to "Tuan Besar of Singapore," dated 13 Zulkaedah 1236 (12 Aug. 1821);

h. A letter from Sultana Siti Fatimah binti Jamaluddin Abdul Rahman of Pamanah to Colonel William Farquhar, British Resident of Singapore, dated 13 Zulkaedah 1237 (1 Aug. 1822);

i. Letters on Riau:

(1) A letter from Yang Di Pertuan Muda Riau to Colonel William Farquhar, British Resident of Malacca, dated 24 Zulkaedah 1233 (25 Sept. 1818);

(2) Twenty-two letters addressed to Major or Colonel William Farquhar, British Resident of Singapore:

(a) from the Shabandar of Riau

(i) dated 25 Zulkaedah 1233 (26 Sept. 1818)

(ii) dated 25 Zulkaedah 1233 (26 Sept 1818)

(iii) dated 3 Safar 1236 (10 Nov. 1820);

(b) A letter from Yang di Pertuan Muda of Pulau Penyengat, dated 5 Rabiulthani (Jumadil Akhir?) 1234 (1 Feb. 1819); 
(c) Four letters from Tengku Pengeran of Siak [Sri Indrapura]:

(i) dated 11 Rejab 1234 (6 May 1819)

(ii) dated 19 Jumadil Akhir 1236 (22 Feb. 1821)

(iii) undated

(iv) dated 23 Rabiul Ackhir 1237 (17 Jan 1822);

(d) Two letters from the Acting Yang di Pertuan Muda of Riau:

(i) dated [1819?]

(ii) dated 10 Ramadhan 1234 (3 Jul. 1819);

(e) A letter from Tengku Besar of Kampar Pulau Daun, dated 1235 A.H. (8 Oct. 1820) Nov. 1819);

(f) A letter Dato' Seri Pikrama Raja of Siak Sri Indrapura, dated 18 Muharram 1235 (6

(g) Two letters from Egku Syed al-Syarif Muhammad Zain ibn almar-hum al-Habib al-syed Abdul Rahman al-Kudsi of Lingga:

(i) dated 17 Ramadhan 1235 (28 Jun. 1820);

(ii) dated 4 Maulid (Rabiul Awal) 1236 (1820);

(h) A letter from Engku Syed Muhammad Zain ibn al-marhum al-Habib Abdul Rahman al-Qudsi of Riau, dated 9 Jamadil Awal 1236 (12 Feb. 1821);

(i) A letter from Sultan Syed al-Syarif Abdul Jalil al-marhum Saifuddin Yang Di Pertuan Besar Siak Indrapura, dated 20 Jamadil Akhir 1236 (23 Feb. 1821);

(j) A letter from Tengku Long of Riau, dated 17 Safar 1227 (20 Feb. 1812);

(k) Two letters from Yang Di Pertuan Muda Riau:

(i) dated 10 Rabiul Awal 1231 (9 Feb. 1821)

(ii) dated 8 Syawal 1237 (28 Jun 1822);

(1) A letter from Colonel William Farquhar, British Resident of Singapore to Yang Di Pertuan Muda Riau, dated 25 Rabiul Awal 1237 (20 Dec. 1821);

(m) A letter from Dato' Syahbandar of Lingga to Baba Hock Kee of Singapore, dated 23 Syawal 1236 (24 Jul. 1821);

(n) letters from Trengganu:

(1) from Sultan Ahmad ibn Sultan Zainal Abidin to Colonel Farquhar, British Resident of Malacca, dated 1 Zulhijjah 1234 (21 Sept. 1819);

(2) from Sultan Ahmad ibn Sultan Zainal Abidin to Colonel William Farquhar, British Resident of Singapore

(i) dated 29 Rejab 1234 (24 May 1819)

(ii) dated 5 Syaaban 1237 (1822);

(3) From Sultan Abdul Rahman ibn Sultan Zainal Abidin, Yang Di Pertuan Muda, Acting Sultan of Trengganu, to Colonel William Farquhar, British Resident of Singapore: 
(i) dated 27 Muharram 1235 (15 Nov. 1819);

(ii) dated 12 Muharram 1236 (20 Oct. 1820).

\section{IV}

The early printed books in this collection, although few in number, nevertheless represent a body of literature which is important both for the study of the historical development of the Malay language and for the history of printing in the Malay archipelago. As noted earlier, all but one are in the Arabic or jawi script and were printed in various places: Great Britain, India, Malaysia, the Netherlands, and Singapore. The earliest title in the collection is in the roman script and was printed at Oxford, England, in 1677. Only a few printed books bear the "Smithsonian Deposit" stamps. It may therefore be assumed that not all of the books came to the Library in the Smithsonian Deposit of 1865, but most were acquired separately over the years.

Those books printed by the Mission Press serve as examples of the early printing presses in the region. In Malaysia and Singapore, for example, the first printing press was started on Prince of Wales Island, Penang, in 1806, followed by missionary presses in Malacca in 1815 and in Singapore in 1822. It was the Mission Press that brought out early imprints in the Arabic script in 1817 bearing the titles "The Ten Commandments" with "The Lord's Prayer" appended, and "Dr. Watts' First Catechism."

The early printed books in the collections can be described as follows:

1. Bibles:

a. The Bible: Old and New Testament or Al-Kitab iaitu segala Surat Perjanian Lama dan Baharu; tersalin kepada Bahasa Melayu atas titah segala tuan pemerintah Kompani Wolanda Tentera di Bandar Betawi pada tahun 1758. Rev. ed. Calcutta: R.S. Hutchings, 1821. 1453 p.

b. Songs of David with Prayers or Pujizan yaitu segala Zabur Daud lagipun beberapa doa yang dipakai sehari, pagi dan petang. 2nd ed. Singapore [s.n.] 1831. 273 p.

c. The Bible: Old and New Testament or Al Kitab iaitu segala Surat Perjanjian Lama dan Baharu; tersalin kepada Bahasa Melayu atas titah dan belanja kerapatan al-kitab di Wolanda iaitu tuan 2 yang ada rapat akan memberita firman Allah daripada banyak kesalahan bahasa tesuci dan tertera pula. Harlem: Johannes Enschede, 1824. 778 p.

d. The Bible: Old Testament or Al-qul al-atif iaitu segala Surat Perjanjian Lama.

[Tersalin] atas titah dan belanja kerapatan al-kitab di Wolanda iaitu tuan2 yang ada rapat memberita firman tersuci dan tertera pula. Harlem: Johannes Eschede, 1824. v. 2 (p.779-1304)

e. The Bible: New Testament or Wasiat yang Baharu iaitu segala Kitab Perjanjian Baharau atau Injil tuhan kami Isa a-Masih. . Tersalin kepada Bahasa Melayu pada kedua kalinya dan lagi dicap atas belanja Netherlands Bible Genootschap [S.I.: s.n.]. 1889. 683 p. Lithograph.

f. The Bible: New Testament or Injil al-Kudus Isa al-Masih iaitu segala Surat Perjanjian Baharu. [Tersalin] atas titah dan belanja kerapatan al-kitab di Wolanda iaitu tuan yang ada rapat akan memberi firman Allah daripada banyak kesalahan bahasa tersuci dan tertera pula. Harlem: Johannes Enschede, 1820. 423 p. 
g. The Bible: New Testament or Kitab al-Kudus iaitu Injil Isa al-Masih atas segala Surat Testament Baharu. Rev. ed. Singapore: The Mission Press for the British and Foreign Bible Society, 1831.2 v. (953 p.) v, 2 bound with v. 1.

2. Malay Textbooks.

a. Keasberry, B.P. Ini kitab teki2 terbang iaitu pada menyatakan daripada permulaan belajar alif ba ta sampai boleh membaca dan mengarang surat 2 Melayu. Singapore: Malay Missionary Singapore [1872] $165 \mathrm{p}$.

Also contains Ceritera ilmu kepandaian orang puteh. $165 \mathrm{p}$.

Lithograph. 356).

b. Hikayat Jaya Asmara. Singapore [s.n.] 1899. 3 v. LC has v. 2 (p.101-270); v. 3 (p.271-

"Akan menjadi pergunaan kepada kanak2 yang belajar dalam sekolah2 Melayu supaya mengetahui jalan Bahasa Melayu yang betul."

Lithograph.

c. Nuruddin ar-Raniri, Sheikh. Bustan as-salatin. Bab Yang Kedua. Singapore: American Mission Press, 1900. 128 p.

d. A collection of four titles:

(i) Karangan perkataan pendek. 3rd ed. Singapore [s.n.] 1836. 11 p.

(2) Ibarat perkataan. 3rd ed. Singapore [s.n.] 1836. 16 p.

(3) Beberapa hal kelahiran orang 3rd. ed. Singapore [s.n.] 1836. 20 p.

(4) Ibarat pelayaran kehidupan 3rd. ed. Singapore [s.n.] 1836. 28 p.

3. The Works of Munshi Abdullah bin Abdul Kadir

a. Hikayat Abdullah. (The Story of Abdullah)

(1) Hikayat Abdullah. Bahawa inilah jilid yang kedua begi Hikayat Abdullah bin Abdul Kadir Munshi. Singapore: Matbaah Government, 1888. v. 2 (p.243-487).

(2) Hikayat Abdullah bin Abdul Kadir Munshi. Singapore: Sidang Methodist, 19151917. v. 1 (165 p.); v. 2 (p. 166-339). Bound with v.1.

b. North, Alfred, and Abdullah bin Abdul Kadir.

Bahwa ini ceritera kapal asap [An Account of the Steam Ships] (Singapore: Mission Press, 184?). $86 \mathrm{p}$.

The first nineteen pages contain an account from Abdullah of his visit to the steamship Sesostris which lay at anchor at Singapore in 1841. An account of this visit is also related by Abdullah in his Hikayat Abdullah. The rest of the pages are written by Alfred North, relating the power and uses of steam. In the last pages, 67-86, North urges Malays to move away from the Arab sphere of influence.

4. Two publications of Sejarah Melayu:

a. North Publications:

(1) 1st ed. Preface by Alfred North. Singapore: Mission Press [1840] 5, 368 p. 
According to a note found in the cover, the Sejarah existed only in manuscript until 1841 when it was printed in Singapore at the expense of Thomas MacMicking Esq. under the careful supervision of Mr. Alfred North, assisted by Abdullah. The work is said to have been collated from six manuscripts.

(2) 2nd ed. Preface by Alfred North. Singapore: Mission Press [1840] 5, 368 p.

According to a note found inside the cover, the work was collated from various manuscripts with the help of a "learned native" (i.e. Abdullah bin Abdulkadir Munshi) and was first printed in 1840.

This edition contains thirty-four chapters and ends with the death of Tun Ali Hati.

b. Shellabear Publication. Singapore: Mission Press [1896] 7, 345 p.

"Segala perkataannya dibandingkan dengan beberapa kitab tulisan tangan dan kitabkitab yang tercap dahulu maka barang perkatannya yang salah telah dibetulkan oleh tuan W. J. Shellabear."

5. A collection of religious tracts published by a Christian missionary in Singapore in the 1830 s.

The Library of Congress has only one roman script title in this collection: Jang Ampat Evangelia derri Tuan Kita Jesu Christi, daan Berboatan derri Jang Apostoli Bersacti. Bersalin dallam bassa Malayo; that is The Four Gospels of Our Lord Jesus Christ, and the Acts of the Holy Apostles, translated into the Malayan tongue. Oxford: Printed by H. Hall, 1677. 14, 215 p.

This translated work is unique because of its written testimony to the use of the Malay language-the percursor of the present Bahasa Indonesia and Bahasa Melayu spoken in Malaysia, Brunei, and Singapore-as the lingua franca of the Malay world in the seventeenth century. The introduction contains some information about other early translations into Malay of books of the Bible, as well as information about dictionaries by the translator.

\section{$\mathbf{V}$}

This collection of Malay manuscripts and early printed books constitutes a unique source of material for historical and comparative philological studies. For research purposes, the volume containing official correspondence consisting of forty-six letters by heads of governments in Southeast Asia is a real find, enriching resources available for the study of early nineteenth-century history in Indonesia, Malaysia, and Singapore. Almost all of the letters concern the establishment of friendly relations with the British power seated in Singapore. It is quite evident from reading the correspondence that British supremacy in the area was so respected that even a ruler of Palembang felt compelled to send a letter of greetings to Tuan Besar ("big boss").

While the correspondence casts light on the nature of the political relationship between the British power and Malay rulers, Hikayat Abdullah, one of the Malay manuscripts in the collection, provides a most colorful description of social changes in the Malay world under the newly imposed British rule. Abdullah noted, for example, how the Dutch Eurasians in Malacca eagerly adapted themselves to the British way of life, in clothing, customs, and language.

Kitab Adat segala Raja-raja Melayu dalam segala negeri [Customs of the Malay Kings] is another significant source for historical research. It provides insights into the royal life and 
customs of a Malay ruler from the time of his birth to his death, and contains rules of conduct for every aspect of royal life.

For philological purposes, the Library of Congress holdings can be compared with those in the collections described by Ricklefs and Voorhoeve in Indonesian Manuscripts in Great Britain (1977). The Library of Congress Hikayat Abdullah, though copied by a Bugis scribe, Ismail bin Hussein, should be close to Abdullah's original work since it was copied under the close superivison of Alfred North and completed in about five months. When the text of this manuscript is compared with the lithographic text in the Shellabear edition (1915), which purports to be close to Abdullah's original, differences in words and paragraph order alter the interpretation of the events described. Consider the following:

1. Shellabear (p.4): "Kemudian belajar bahasa dan belajar kira. ..."

LC Manuscript (p.4): “Kemudian belajar bahasa Keling dan belajar kira. . . ."

2. Shellabear (p.7): "pada hijrah nabi sanat 1231 tahun maka bapakupun kembalilah ke rahmattullah kemudian. ..."

LC Manuscript (p.6): "pada hijrah nabi sanat 1239 tahun bapakupun kembali ke rahmatullah taala...."

3. Shellabear (p.7): "Sebermula adapun negeri yang tempat aku tumpah darah yaitu negeri Melaka yang dipeliharakan Allah daripada segala bala' dan aniaya maka pada masa itu Inggeris memegang perintah dalam Melaka. ..."

LC Manuscript (p.6): “Sebermula adapun negeri yang tempatku tumpah darah itu yaitu negeri Melaka yang dipeliharakan Allah ... dan aniaya kepada tarikh 1211 sanat tahun kepada tujuh...."

\section{VI}

Let me now turn to what this Malay manuscripts collection means for the library profession in terms of acquiring publications from Southeast Asia. It is quite clear that, in retrospect, the successful acquisition of the manuscripts and early printed books was the product of fortuitous timing and circumstances. Congress authorized and funded the Wilkes Expedition; the expedition was commanded by a naval captain interested in acquiring recorded culture-handwritten or printed materials. However, even more crucial for the success of the mission was the role of an American missionary residing in Singapore by the name of Alfred North, who was known as a Malay expert, a practical printer, and, above all, a Malay bibliophile.

No matter how well the expedition was funded or how keen the interest shown in acquiring research materials from Southeast Asia, success would have been far less likely in the absence of a cultural go-between; someone with a mastery of the local language and the book trade in the region. When the expedition arrived in Singapore in 1842, there were neither national bibliographies nor book publishers, nor bookshops to turn to for acquisitions. It was indeed fortunate that Alfred North was around. He knew the country well: its people, culture, language, and, above all, where important materials were to be purchased.

Being a bibliophile, he had apparently cultivated a friendship with Malay authors and scribes and could identify those he thought to be the best among them. Not only did he encourage them to write or copy works wanted by the expedition, but he also published their works with his missionary printing press. Thanks chiefly to his efforts, significant 
records of the cultural heritage of the ethnic Malay population of Brunei, Indonesia, Malaysia, and Singapore, was preserved for many generations to come.

Alfred North was born on March 19, 1807 in Exeter, New Hampshire. His family having moved to two different states before he reached the age of twelve, he attended schools in West Windsor, Vermont, and in Boonville, New York. Finally, in 1823, he attended a denominational school in Utica, New York, where he received instruction in religious subjects, including religious music. In addition, he was tutored in music as well as trained in printing by Thomas Hastings, a noted composer and publisher of The Western Recorder.

In 1832, Alfred North moved to New York City and worked as a printer. There he regularly attended a Protestant religious revival where he met his future wife, Minerva Bryan, who shared his vision of spreading Christianity throughout the world. Not long after he "professed" religion as his way of life in 1833, he married Minerva Bryan. In 1835, both husband and wife received appointments as assistant missionaries by the American Board of Commissioners for Foreign Missions and were sent overseas to Singapore.

A question might arise as to why the newly married young couple wanted to go to that distant land. The answer seemed to be that at the time there was a widespread belief that the millennium was fast approaching. In fact, one minister had even fixed the date for its imminent arrival as 1999 and had suggested that the time had come to save the world for Christ. According to Geoffrey Ward in a recent article, ${ }^{4}$ it was the Rev. Timothy Dwight, President of Yale College, who set the ambitious agenda of the American Board's special mission: that is, to hasten the time "when the Romish cathedral, the mosque, and the pagoda, shall not have one stone left upon another which shall not be thrown down...."

Whatever the case may be, the Norths arrived in Singapore on February 7, 1836 on board the Sachem. In Singapore, North took up studying the Malay language with the famous Munshi Abdullah Kadir. In his article "The 'Lost' Manuscript of Hikayat Abdullah,"5 H.F.O'B. Traill wrote that in Singapore North studied Malay with Abdullah, who thought of him as one "who has bathed in the waters of the Malay language and drunk his fill of them." When North completed his assignment in Singapore, he was given another missionary assignment. This time it was in India. He, along with his family, left Singapore for India on board the Shah Alam on November 20,1843. In 1847, two years after his wife had died of cholera, he was summoned home by the Commissioners for Foreign Missions. Although he was asked to return to India, North decided to stay home and entered Auburn Theological Seminary to qualify for Presbyterian ministry. He died on March 3, 1869, in Chilton, Wisconsin.

\section{VII}

In this article I have attempted to describe the provenance and contents of the Library of Congress holdings of Malay manuscripts and early printed books, highlighting the role played by Alfred North in acquiring the materials for the Wilkes Expedition. I have argued that this collection represents a body of literature which is important for the study of the historical development of Malay language and society and also for the history of printing in insular Southeast Asia. No other library institutions, except the British Library, appear to

\footnotetext{
${ }^{4}$ Geoffrey C. Ward, "Two Missionaries' Ordeal by Faith in a Distant Clime," Smithsonian 21, 5 (1990): 118-32

${ }^{5}$ Dato H.F.O'B. Traill, "The 'Lost'Manuscript of Hikayat Abdullah Munshi," Journal of the Malaysian Branch of the Royal Asiatic Society 15, 2 (1982): 126-34.
} 


\section{A. Kohar Rony}

have examples of the Malay manuscripts and early printed books at the Library of Congress. Indeed, two copies of the Sejarah Melayu held at the Library of Congress are the only copies extant: neither the British Library nor the National Library of Malaysia have copies of them in their holdings. More importantly, they represent the first acquisition of research materials from Southeast Asia by the United States Government. It was not until 120 years later that the acquisition of research materials was resumed in earnest with the establishment of the Library of Congress National Program for Acquisitions and Cataloging in 1963.

\section{APPENDIX}

List of Library of Congress Malay manuscripts:

1. Kinta Buhan

2. Isma Dewa Pakurma Raja or Hikayat Isma Dewa Pekerma Raja

3. Khoja Maimon or Hikayat Khoja Maimon

4. Amir Hamzah or Hikayat Amir Hamzah

5. Hikayat Johor or Salasilah Raja-Raja Johor.

6. Hikayat Patani.

7. Hikayat Muhammad Hanafiah.

8. Hikayat Abdullah.

9. Hikayat Panca Tanderan.

10. Kitab Tib.

11. [Four Tales]

12. Hikayat Syah Mardan.

13. Hikayat Isma Yatim.

14. Adat segala Raja-raja. 